\title{
STRENGTHENING THE EXISTENCE OF ISLAMIC RELIGION EDUCATION IN THE INDUSTRIAL REVOLUTION ERA 4.0 (Study of PAI FAI Curriculum Review of Muhammadiyah Gresik University)
}

\author{
Noor Amirudin \\ Email: amir@umg.ac.id \\ Islamic Education Study Program \\ The Faculty of Islamic Studies at the University of Muhammadiyah Gresik
}

\begin{abstract}
This study provides an overview of the importance of massive reform in the Curriculum of Islamic Religious Education at the Faculty of Islam, Muhammadiyah Gresik University. This reform is needed so that the FAI UMG PAI curriculum can answer the challenges and demands of the times that continue to change globally. Besides, this deafness also poured out the results of a solution to Islamic religious education in the face of the Era of Industrial Revolution 4.0. As it is known, that the Era of the Industrial Revolution 4.0 had a broad impact on all lines of life, including in the field of education, especially Islamic education. The era that gave birth to this disruption phenomenon demanded the world of Islamic religious education to participate in adjusting. Graduates of Islamic education are now faced with new challenges, demands, and needs that have never existed before. So it is necessary to update and innovate the system, governance, curriculum, human resource competencies, facilities and infrastructure, culture, work ethic, and others. Otherwise, Islamic religious education will be increasingly left behind and outdated. Therefore, it is necessary to look for concrete steps for Islamic religious education in order to be able to remain competitive in this disruption era. The solution step is to participate in discussing themselves.
\end{abstract}

Keywords: islamic religious education, industrial revolution 4.0, disruption 


\section{INTRODUCTION}

long with the times, the
challenges and obstacles of
Islamic religious education also continue to experience development and change. If in the past few decades intimate conversations between students and teachers have been taboo, then today is a natural thing. Even in the view of modern education theory, it is a necessity. Such interaction is an indication of the success of the education process.

Another paradigm shift for example in terms of learning approaches. In the era of traditional Islamic religious education, teachers became a central figure in learning activities. It is the primary source of knowledge in the classroom, even the only one. However, in the context of modern Islamic religious education, such case is no longer valid. The role of today's teachers has undergone a shift, namely as a facilitator for students. Learning is no longer teachercentered (teacher centered), but more student-centered.

Shifts and changes as described above are a certain inevitability. This is due from time to time social demands and needs continue to change. Today, extensive knowledge alone cannot guarantee that a graduate can speak much in global

\footnotetext{
${ }^{1}$ https://eduaksi.com/pendidikan-4-0-apa/, accessed 11 February 2019 at 12.44 WIB
}

competition. Specific expertise is also needed that is in line with the needs of the field. If this is not the case, graduates of education will be crushed and excluded. Moreover, now the world has entered a new era, namely the Era of the Industrial Revolution 4.0.

The era of Industrial Revolution 4.0 (from now on: Era 4.0) has an unimportant impact. It affects all aspects of human life. Included in this case is education. This era is characterized by the increasingly central role of cyber technology in human life. So do not be surprised if in the world of education the term "Education 4.0" appears.

Education 4.0 (Education 4.0) is a general term used by education experts to describe various ways to integrate cyber technology both physically and not into learning. This is a leap from 3.0 education which according to Jeff Borden includes meeting neuroscience, cognitive psychology, and educational technology. Education 4.0 is a phenomenon that responds to the need for a fourth industrial revolution in which humans and machines are aligned to find solutions, solve problems and of course discover the possibility of innovations ${ }^{1}$.

Then how is Islamic religious education facing this revolution? How does he take 
advantage of the opportunities that exist and at the same time answer the challenges and overcome obstacles that are not simple? This paper seeks to portray the dynamics of Islamic education curriculum review studies in Era 4.0 and map the strength, weakness, opportunity, and threat (SWOT).

\section{RESEARCH RESULTS DISCUSSION}

1. Understanding of Islamic Education

At least two meanings can be derived from the terminology of Islamic Education. First, education about Islam, secondary education according to Islam. The first terminology is more to regard Islam as $a$ subject matter in education, while the second terminology places Islam more as a perspective in Islamic Education ${ }^{2}$.

Muhammad Hamid An-Nashir and Gullah Abdul Qadir Darwis define Islamic education as a process of directing human development in terms of body, mind, language, behaviour, and religious, social life which is directed towards goodness towards perfection ${ }^{3}$. Meanwhile Omar Muhammad At-Taumi Ash-Syaibani was quoted as saying by M.Arifin, stated that
Islamic education is an effort to change individual behaviour in private life or community life and life in the surrounding environment ${ }^{4}$.

Honestly, it must be admitted that Islamic religious education has been widely understood in the first sense, so the concept of Islamic religious education is more oriented to the material, curriculum and methods of how a teacher delivers Islamic religious education material to students. If the Islamic education is understood in the first sense, then the process that occurs is the transfer of Islamic values (Transfer of Islamic values) from the old generation to the younger generation without having to create conditions that make students think creatively and progressively.

If the second concept understands the notion of Islamic religious education, then it will not view Islam as a set of values that are part of the education system but view education as a process that is part of the Islamic life system ${ }^{5}$. Therefore, it means that Islam is not a subject that must be taught to students, but Islam is more the soul of education itself. Thus, Islam means having concepts about education.

\footnotetext{
${ }^{4}$ Noor Amirudin, Philosophy of Islamic Education, Gresik: Caremedia Communication, 2018, p.15.

5 Mohammad Djazaman, Concept of Islamic Education, Journal of Islamic Education, p.91.
} 
Islamic education is an attempt by cautious Muslim adults to consciously direct and guide the growth and development of fitrah (basic abilities) of students through Islamic teachings towards the maximum point of growth and development ${ }^{6}$. Education theoretically contains the meaning of "feeding" (opvoeding) to the soul of students so that they get spiritual satisfaction, also often interpreted by "growing" basic human abilities. If you want to be directed towards growth following Islamic teachings, you must proceed through the Islamic religious education system, both through institutions and through the curricular system ${ }^{7}$. The essence of electric potential in every human being lies in the faith or belief, science, morality, and experience $^{8}$. These four essential potentials become functional levels of Islamic Education.

2. The Purpose of Islamic Education

In general, Islamic religious education aims to "increase the faith, understanding, appreciation, and experience of students about Islam, so that they become Muslim human beings who believe and fear Allah SWT and have noble deeds in personal life, community, nation, and state ${ }^{9}$.

\footnotetext{
${ }^{6}$ Muhammad Arifin, Islamic Education: Aoretical and Practical Based Review Interdisciplinary Approach, Jakarta: PT.Bumi Aksara, 2003, p.22.

${ }^{7}$ Noor Amirudin, Philosophy of Islamic Education, p.22.
}

From these objectives, several dimensions can be drawn that are intended to be improved and aimed at learning activities of Islamic religious education, namely: a) the dimensions of the faith of students in the teachings of Islam; b) dimensions of understanding or reasoning (intellectual) and scientific learning of students towards the teachings of Islam; c) dimensions of appreciation or inner experience felt by students in carrying out Islamic teachings; and d) the dimensions of his experience, in the sense of how Islamic teachings that have been believed, understood and biological or internalized by students are able to foster motivation in him to move, practice, and wait for the teachings of religion and values in personal life, as believing human beings and fear Allah SWT and actualize and realize it in the life of society, nation and state.

In line with the description above, Athiyah al-Abrasyi revealed that there are five primary goals of Islamic education. First, it forms a noble character. According to him the formation of noble character is the spirit of Islamic education. This is in harmony with the primary purpose of sending the Prophet to this world, namely to perfect human morals. Second, provision of

\footnotetext{
${ }^{8}$ Moh.Fadhil al-Djamali, al-Tarbiyah al Insan aljadid (Tunisia al-Syghly: Matba'ah al-Ittihad al'Aam, 1967), p.85.

${ }^{9}$ Muhaiman, Paradigm of Islamic Education, Band of PT.Teenager Rosdakarya, 2004, p.78.
} 
life in the world and the hereafter. Islamic religious education not only giving attention in religious terms, nor was the merely mundane. Islamic education provides equal attention to both. Third, grow scientific spirit and satisfy taste want to know (curiosity). Fourth, prepare students in terms of professional, technical and company so that he can master certain professions, so that he can seek sustenance in life and life with dignity. Fifth, preparation for sustenance and maintenance of facets of benefit. As stated earlier, Islamic education does not only focus on moral formation but also aims to provide knowledge of the world to students. The provision is in the form of specific skills that can be used by students to participate in competing in life ${ }^{10}$.

\section{Problems with Islamic Education}

The fundamental problem in education in Indonesia is the low quality of education. This is indicated, with the still high imbalance in the quality of education between regions. Indicators of education development at the provincial level show two trends, namely in the category above the national standard and below the national standard ${ }^{11}$. Indicators of education quality can be seen from participation rates, dropout rates, repetition rates, teacher-student ratios,

10 Zuhairini, Philosophy of Islamic Education, Jakarta: Bumi Aksara, 2015, p.164-166.

${ }^{11}$ Siti Irene Astuti Dwiningrum, Decentralization and Community Participation in Education: A school-teachers, teacher eligibility rates, and conditions for school infrastructure.

This educational quality gap is multidimensional. Based on the phenomenon that continues to develop at this time, there are at least three main reasons, namely: First, education undergoes a process of reducing meaning, even degraded only memorizing activities and skills in working on exam questions (UN). Second, education falls into the process of commercialization, where education has turned into a commodity that is traded or traded and managed, like the industrial world which tends to be profit-oriented (profit oriented). Third, education only gives birth to the superiority of schools, namely schools becoming more powerful, distant, and pressing on parents of students, both subtly, and openly ${ }^{12}$.

Islamic education in its existence as a component of nation-building, especially in Indonesia, plays a huge role and this has been going on long before the independence of the Indonesian nation. This can be seen in the practice of Islamic religious education organized by Muslims through traditional educational institutions such as majelis

Theoretical and Empirical Study, Yogyakarta: Student Library, 2011, p.289.

${ }^{12}$ Siti Irene Astuti Dwiningrum, Decentralization and Participation, p.295. 
taklim, pengajian forum, surau and pesantren which thrive and exist until now ${ }^{13}$.

As with national education, Islamic education in Indonesia is also being plagued by tiring problems. Because Islamic education is a national education subsystem, then when national education is considered a failure because there are still many problems that have not been successfully resolved it must be admitted that it is also a failure of Islamic education. If you pay close attention, Islamic education in the middle of the day is faced with internal and external problems.

Internal problems can be seen in the ethos of Islamic education today seen from the Islamic school education system that is managed, such as Islamic boarding schools, Islamic schools, and Islamic colleges (UIN / IAIN / STAIN, PTAIS, etc.) are actually quite encouraging, or even if not, the number exceeding the need for overproduction, while other sciences oriented to science and technology are still scarce. So it is logical if there is an assumption that states, "Islamic students are poor about insight, mastery of science and technology, communication, and also politics." It is not wrong to conclude that the ethos of Islamic education as it is

\footnotetext{
${ }^{13}$ Ahmad Arifi, Politics of Islamic Education Tracing the Ideology and Actualization of Islamic Education in Middle of Globalization, Yogyakarta: Teras, 2010, p.2.

${ }^{14}$ Ahmad Barizi, (Ed), Integrative Education in the Roots of Tradition \& Integration of Educational
}

today is still not paying attention to the link and match in building its education system ${ }^{14}$.

Syamsul Ma'arif stated that Islamic education at this time was indeed in a deplorable and alarming condition. Islamic education experienced a deterioration far behind with Western education. If you may be a little nostalgic, Islamic education cannot be like in the golden age (Andalusia and Baghdad) which could become the center of Islamic civilization, both in the fields of culture, art or education. What happened was just the different, Islamic education now followed and was oriented towards the West. With the supremacy of knowledge controlled by developed countries, Muslim countries continue to depend on the West in almost all lives: defence and weaponry, communication and information, economics, trade, education, and scientific development ${ }^{15}$.

This is a shameful irony given the vastness of the Quranic concept of education. The lag can be seen from at least the existence of madrasa and pesantren which used to have a strategic role in delivering the development of Indonesian society, now the enthusiasm of the community to enter madrasa and pesantren education (especially those still mumbling

Sciences Islam, Malang: UIN-Maliki Press, 2011, p. 7

${ }^{15}$ Syamsul Ma'arif, Revitalization of Islamic Education, Yogyakarta: Graha Ilmu, 2007, p.1-2. 
with the "salaf" system) has decreased dramatically. Except for boarding schools (modern), that can adapt to global development. The public's pessimism towards madrasa education and Islamic boarding schools can be seen from the universal concern about the ability of graduates to enter new jobs that are only open to those who have skills and mastery of technology 16 .

As "criticisms" often raised by Islamic education thinkers, why Islamic education is still very far behind with the West, because of several reasons, including: first, the orientation of education is still neglected do not know the direction of the destination which should be appropriate with Islamic orientation. Islamic education is only concerned with the transfer of religious knowledge. Hereafter, of course, is everything, while world affairs are later. Besides, it is still definitive in that it means saving Muslims from all the pollution and destruction caused by Western ideas that come through various scientific disciplines that can threaten the standards of traditional Islamic morality.

Secondly, the practice of Islamic education still maintains an old heritage, so that the scientists studied is classical science

\footnotetext{
${ }^{16}$ Ahmad Barizi, (Ed), Integrative Education in the Roots of Tradition \& Integration of Educational Sciences Islam, Malang: UIN-Maliki Press, 2011, p.5.
}

and modern science is untouched. The sources referenced are only yellow books and are considered as the standard and prima donna as a source of inspiration in answering all contemporary issues, which sometimes because no answers are found in the book, then forced to be matched or looked forced.

Third, Muslims are still busy lulled by the romance of the past. The greatness of the past Muslims up to now still influences the Muslim mindset. They are still proud of the glory of the past, but not aware that pride is precisely what causes backwardness. Therefore, most of them are very lazy to make efforts to renew and lose quickly with social, political, and technological advances in science and technology.

Fourth, the learning model of Islamic religious education still emphasizes verbalistic intellectual approach and negate educational interaction and humanistic communication between teacher and student. So that the education system is still barren, backward and deadly the power of child criticism, aka not educating and freeing children ${ }^{17}$.

The implication of the learning model is the students' creativity. Education becomes deprived of its essence. Education should be an effort to free people from the shackles of

\footnotetext{
${ }^{17}$ Syamsul Ma'arif, Revitalization of Islamic Education, Yogyakarta: Graha Ilmu, 2007, p.2-3.
} 
ignorance through humanistic ways that respect the potential of students and make it capital in developing the abilities and personality of students.

The myriad of problems are still coupled with other internal problems that must be resolved immediately, such as; Muslims are still shackled and trapped in the dichotomy of Islamic religious education, the narrow understanding of the essence of Islamic teachings, the format of the curriculum which is not clearly oriented and the lack of quality human resources, systems and strategies developed, methodology and evaluation, and the implementation and implementation of Islamic exclusive, not yet willing to interact and synchronize with others.

While the external problems faced by Islamic religious education are in the form of various advances in science and technology which have resulted in the emergence of scientific critique of traditional, textual, conservative and ritualistic religious explanations.The era of globalization in the field of information and socio-economic and cultural changes with all its effects. Included among them is the 4.0 industrial revolution which will be explained in the following description. Another challenge is the plurality of religious communities that are still not ready to differ in understanding and instead behave fanatically absolutist, apologists and truth claims are wrapped up with personal interest nodes or those that are political or sociological.

4. The era of the Industrial Revolution 4.0

The industrial revolution consists of two (2) words namely revolution and industry. Revolution, in the Great Indonesian Language Dictionary (KBBI), means that changes are very fast, while the notion of the industry is an effort to carry out the production process. So if two (2) words are combined meaningfully a change in the production process that takes place quickly. This rapid change is not only aimed at increasing the goods produced (quantity), but also improving the quality of production (quality).

The term "Industrial Revolution" was introduced by Friedrich Engels and LouisAuguste Blanqui in the mid-19th century. This industrial revolution is also running from time to time. The last decade has been called entering the fourth phase 4.0. Changes in phase to phase give articulatory differences in terms of their use. The first phase (1.0) is concerned with the discovery of machines that emphasize (stressing) the mechanization of production. The second phase (2.0) has moved on to an integrated mass production stage with quality control and standardization. The third phase (3.0) enters the stage of mass uniformity which 
relies on computerized integration. The fourth phase (4.0) has presented digitalization and automation of the integration of the internet with manufacturing ${ }^{18}$.

The fruit of the 4.0 industrial revolution is the emergence of a disruptive phenomenon innovation. The impact of this phenomenon has spread in all areas of life.
Starting from industry, economy, education, politics, and so on. This phenomenon has also succeeded in shifting the lifestyle (lifestyle) and mindset (mindset) of the world community. Simple disruptive innovation can be interpreted as a phenomenon of disruption of incumbent actors by new industry players due to the ease of information technology.

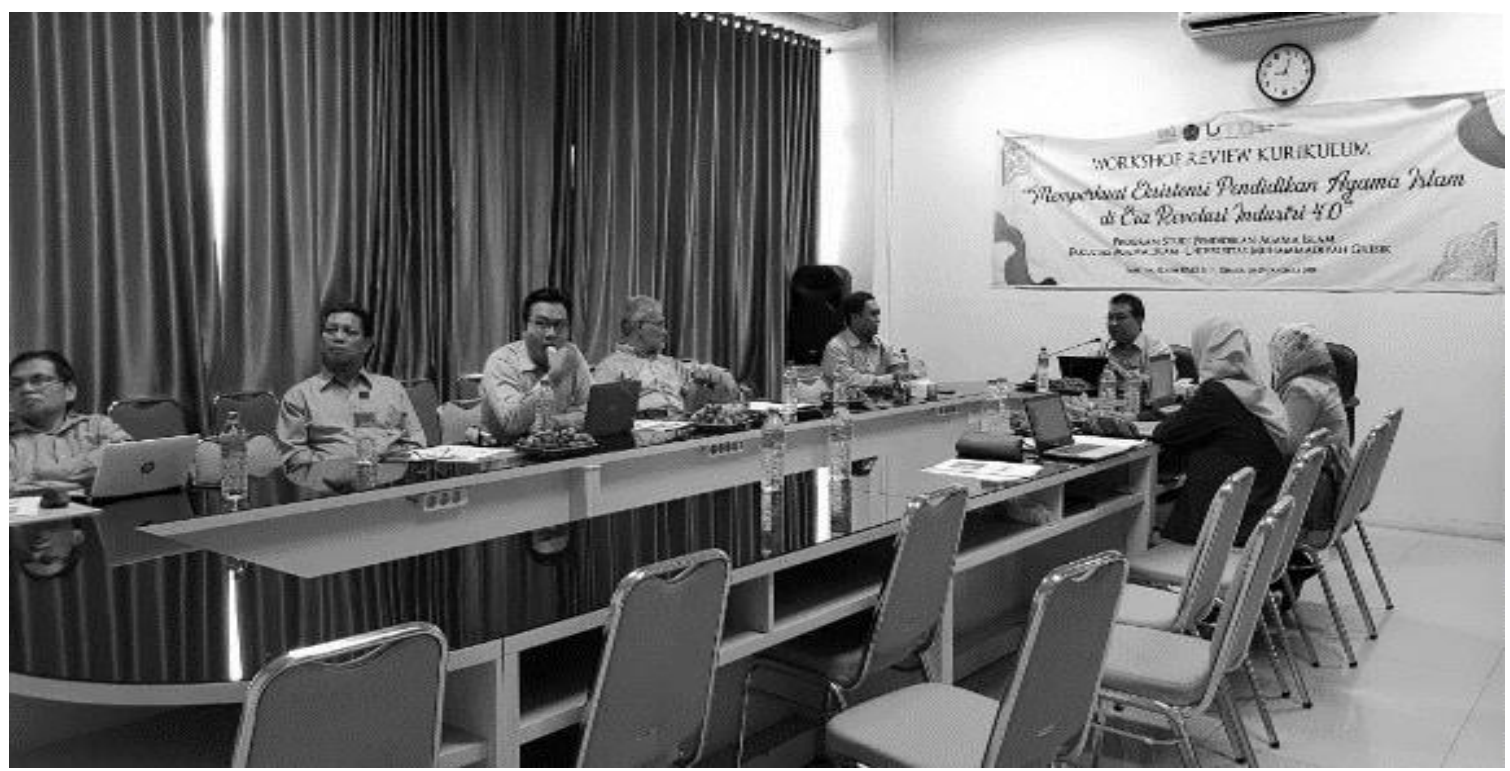

Picture 1. Dr. Suyoto, M.Sc.

as a speaker in the PAI FAI UMG Review Curriculum

One of the many examples around us is the declining income of motorcycle taxi drivers and taxi companies. This decrease in income was not caused by a decrease in the number of motorcycle taxi and taxi users, but a change in consumer behaviour. Thanks to the advancement of information technology, new transportation companies have emerged, such as GO-JEK, GRAB, and UBER, whose services are based on

18 Hendra Suwardana, Industrial Revolution 4.0 Based on Mental Revolution, UNIQUE TEAK, Vol.1, No.2, (2017), p.102-110. 
Android. Consumers only need to install the application on their smartphone to use their services. Besides, the tariff installed is also much cheaper. These three new players caused the necessary transportation services to suffer losses ${ }^{19}$.

Besides, the phenomenon of disruptive innovation also caused several professions to disappear because machines replaced them. For example, now all the work of the checkin counter staff at various international airports has been taken over by machines that can directly answer passenger needs, including scans to check passports and visas, and printers to print boarding passes and luggage $\operatorname{tags}^{20}$. Another impact is the emergence of new professions none before, like Youtuber, Website Developer, Blogger, Game Developer and so on.

The advantages of the emergence of disruptive innovation provide, among others: First, the convenience of consumers in meeting their needs. By cutting costs incurred, companies that use the latest technology can reduce costs so they can set prices far lower than incumbent companies. Thus, the cheaper the costs incurred by consumers make consumers more prosperous.

\footnotetext{
${ }^{19}$ Dr.Suyoto, M.Sc., as the speaker in the Review of the Islamic Religion Education Study Program curriculum at the Faculty of Islam, Muhammadiyah Gresik on 28-29 January 2019 at the UMG Meeting Room7.
}

Second, a technology that makes it easy. The emergence of new innovations, of course, will bring new and sophisticated technology, at least compared to existing technology. Thus it can be said that there is a technology transfer towards a more modern one. Third, spur innovation-based competition. Indonesia is a country that cannot just prosper without innovation. With the existence of disruptive innovations, companies in the industry are forced to innovate so that they continue to improve their services.

Fourth, reducing the number of unemployed. The innovation will be done to provide new employment opportunities. If you do not open a new field, you can at least expand your existing employment. Especially with innovation, it can provide new employment opportunities with better wages than from existing jobs. Fifth, increase economic growth. Disruptive technology following Schumpeter's theory will increase productivity due to efficiency. With these two things, it will increase the quality and quantity of goods produced. On the other hand, innovation will also increase public consumption after previously his income increased. The development which is the endpoint is the increasing number of

20 Rhenald Kasali, Disruption "Nothing Can Be Changed Before Facing Motivation Is Not Enough" Facing the Invisible Opponents of the Ube Civilization, Jakarta: PT Gramedia Main Library, 2017, p.16. 
Gross Domestic Product. If every innovation can produce greater added value and relatively survive every year, it will increase economic growth in the long run ${ }^{21}$.

5. Welcoming 4.0 Islamic Education

The industrial revolution 4.0 with its disruptive innovation put Islamic education at a crossroads. The intersection has its implications. Islamic education is free to choose from. If he chooses the intersection of the pattern and sticks with the old system, then he must be willing and legowo when getting left behind. Conversely, if he opened himself, would accept the era of disruption with all the consequences, then he would be able to compete with others.

Referring to the results of a study from McKinsey in 2016 that the impact of digital technology towards the 4.0 industrial revolution in the next five (5) years there will be 52.6 million types of work will experience a shift or disappear from the face of the earth. The results of this study give the message that every self who still wants to have self-existence in global competition must prepare mentally and skills that have $a$ competitive advantage from others. The

\footnotetext{
${ }^{21}$ Edy Suandi Hamid, Disruptive Innovation: Benefits and Disadvantages in Context Economic Development, https://law.uii.ac.id/wpcontent/uploads/2017/07/2017-07-27-fh-uiisemnas-disruptive-innovation-faat-dankekurangi-dalam-konteks - $\quad$ economic development - Edy-Suandi-Hamid.pdf, accessed February 11, 2019.
}

primary way to prepare the most natural skills to take is to have good behaviour (behavioral attitude), increase selfcompetence and have a literacy spirit. Provision of self-preparation can be passed with the education path (long life education) and self-concept through the experience of working across generations / across disciplines (experience is the best teacher) ${ }^{22}$.

Based on these facts, it is necessary to reform or reform within the body of Islamic education. Islamic education in the era of 4.0 needs to participate in disrupting itself if it wants to strengthen its existence. Selfdisruption means adjusting to the needs and demands of society and being oriented in the future. Muhadjir Efendy in his speech said that there needs to be school reform, capacity building and teacher professionalism, a dynamic curriculum, reliable facilities and infrastructure, and the latest learning technology so that the world of national education can adjust to the dynamics of the times ${ }^{23}$.

The lag of Islamic education so far, in addition to being caused by problems as described earlier, was also caused by

22 Hendra Suwardana, Industrial Revolution 4.0 Based on Mental Revolution, UNIQUE TEAK, Vol.1, No.2, 2017, p.102-110.

${ }^{23}$ Febrianto Adi Saputro, Mendikbud Reveals How to Deal with Revolution 4.0 in Education, https://www.republika.co.id/berita/pendidikan/ed uaction/18/05/02/p8388c430-mendikbud-ecahcara-h Face- -40-in-education revolution, accessed Wednesday, February 11, 2019. 
potential problems that did not meet the estuary. Rosidin ${ }^{24}$ revealed that four factors were causing Islamic education to get sharp criticism often. First, cultural lag or cultural gap. This is due to the imbalance between the speed of development of science and technology and the speed of development of education. The pace of acceleration of the development of science and technology is not accompanied by efforts to Islamic education to participate in accelerating. As a result, Islamic education is less responsive to the dynamics of social change in society. So that it becomes a necessity if the educational process in it becomes less contextual.

Second, second class stigma. This second factor can be said to be a result indirectly from the first factor. The slowness of Islamic education in responding to the dynamics of the development of science and technology and social reality caused the stigma of comfortable second class embedded in it.

Third, science dichotomy. Until now the dichotomy between Islamic science (PAI) with general science (Science, Social Sciences, Language-Humanities) is still a homework for Islamic education. Although there have been many integration efforts

\footnotetext{
${ }^{24}$ Rosidin, Islamic Education Problems Maqasid Shari'ah Perspective, Maraji ': Journal of
}

between the two, but have not shown significant results.

Fourth, political dualism. Withdrawal of interests between the two institutions Education policymakers in this country often creates polemics among the grass root. Despite many protests and complaints filed, but there is no standard solution to this problem. The policy differences between the Ministry of Education and Culture (Kemendikbud) and the Ministry of Religion (Ministry of Religion) often trigger polemics. Problems regarding salaries, certification, educator incentives and so on are examples of this factor.

In order to meet Islamic Education 4.0, then inevitably all the potential problems above must be able to find a solution. If not, it will be difficult - if it is reluctant to say it is impossible - realizing contextual Islamic education towards the times. Therefore, as stated above, there needs to be reform and renewal of all aspects of Islamic education. Borrowing the term Rhenald Kasali, there are three steps that Islamic education must take in this era 4.0, namely disruptive mindset, self-driving, and reshape or create.

Disruptive mindset. Mindset is how humans think that determined by the settings we make before thinking and acting ${ }^{25}$.

Studies Islam, Vol.3, No. 1, September 2016, p.186.

${ }^{25}$ Rhenald Kasali, Disruption, p.305. 
Islamic education today is in a fast-paced digital age, high mobility, access to information is everyone's primary need. Besides that, today's society demands immediate and real-time. Everything needed must be immediately available. If access to these needs takes too long, the community will leave and move to other services. In essence, the demand in this disruption era is a response.

Response speed will significantly affect the user. This is called Rhenald Kasali as a corporate mindset (corporate mindset). This mindset needs to be built by Islamic education actors so that the services provided to users are no longer bureaucratic. Rhenald said, the characteristics of people with a corporate mindset are; first, not bound by time and place. It works not limited to hours and workspace. People like this have realized that time and place are no longer a barrier to work. Technology has turned it off. Humans today can be connected 24 hours a day, 7 days a week, without being bound by time and place. If the mindset is applied in the management of Islamic education institutions, an effective and efficient managerial system will be formed. Furthermore, when drawn in the context of learning, the teacher will be more flexible and flexible in carrying out their duties and functions.
Second, to provide proactive services. Learning activities still concentrated on the transfer of knowledge from the teacher and confined in the classroom; it will be challenging to produce graduates who are highly competitive. The education paradigm has changed, no longer teacher-centered, but student centered. Teachers are required to be more proactive in providing facilities, guidance, and assistance to students.

Third, not fixated on the budget. Unlike the mental bureaucrats that is all tied to costs (not working if there is no budget).People with a corporate mindset do not stop innovating because of money constraints. Fourth, maximizing the function of social media. Managers of Islamic education today must be able to take advantage of the progress of available communication media. Social media is no longer just entertainment. $\mathrm{He}$ has transformed into a useful communication tool, work aid, and inspiration in innovation. This opportunity must be able to be appropriately utilized.

Fifth, think solution when faced with a problem. Not busy think of reasons to save yourself.Sixth, not allergic to change. In the present era, change has become a necessity. An institution if it persists/is static in its management, will be defeated by an institution that has more dynamic management. 
Moreover, seventh, think and act strategically. Steps in managing Islamic education institutions must have a clear roadmap. The stated objectives must be realistic. Therefore, curriculum reorientation and the vision of primary Islamic education to be carried out. Annual curriculum, vision, program, semester programs must be transparent, flexible, contextual, and futuristic.

Self-Driving. Organizations that are agile and dynamic in their adaptation wading through ocean disruption is an organization that has HR (Human Resources) mentally good drivers (good drivers), not passengers (passenger) $^{26}$. [26] HR with right driver mentality will want to open themselves up, quickly and accurately read the situation, have integrity, be agile in acting, be aware of all bad possibilities, and can work effectively, innovatively and efficiently. These abilities are mainly needed by leaders and managers of Islamic education institutions. They are required to be reliable drivers for their institutions. Therefore, managerial competence alone is not enough. However, it must also be accompanied by the ability to lead while human minded passengers will tend to be bureaucratic, rigid, slow, and lacking in discipline.

Reshape or Create. There are genealogical thoughts that are popular

\footnotetext{
${ }^{26}$ Rhenald Kasali, Disruption, p.16.
}

among the Ummah Islam which until now is still held firm. The genealogy is "keeping the old one good and taking the new one better." As much as mentioned above, that era 4.0 is an era where speed and ease become social demands. This indeed requires massive adjustments. Then there are two logical choices for Islamic education to face this era, namely, reshape or create.

Reshape in the genealogy above means retaining the old ones well. However, in the era of 4.0 to maintain it was not enough, it must be sharpened. Old ways and systems that are still useful and relevant need to be modified following changes and times. For example at the level of management and professionalism of $\mathrm{HR}$, it needs to be strengthened and enhanced by competence and capacity. It can be through training, seminars, workshops, study scholarships, and so on.

Another alternative is to create, create something entirely new or in the genealogy above "taking a new one better. "This means that the old ways and systems are obsolete. So it is not possible to use it again. The only way out is to make an entirely new way and system. For example, they are developing a new digital service system. So that citizens of Islamic education institutions can freely access all the needs related to education and administrative services. Another example, 
Noor Amirudin - Strengthening The Existence...

developing a contemporary learning model by fully utilizing digital technology, such as E-learning, Blended Learning, and so on.

\section{COVER}

Entering this disruption era, Islamic education is required to be more sensitive to the symptoms of social change in society. Islamic education must be willing to disrupt itself if it is to strengthen its existence. Insisted on ways and the old system and the shutdown of the development of the world will increasingly make Islamic education increasingly worse and obsolete (obsolete). Therefore, three things should be pursued by Islamic education, changing the old mindset confined bureaucratic rules, into the disruptive mindset (disruptive mindset) that promote the corporative ways. Islamic education must also do self-driving so that it can innovate according to the demands of the era of 4.0. Besides, Islamic education must also make reshape or create for all aspects in it to always be contextual to the demands and changes.

\section{BIBLIOGRAPHY}

al-Djamali, Moh. Fadhil. 1967. al-Tarbiyah al Insan al-jadid .Tunisia al-Syghly: Matba al-Ittihad al-'Aam.

Arifi, Ahmad.2010 The Politics of Islamic Education Tracing Ideology and
Actualization Islamic Education in the Flow of Globalization.Yogyakarta: Terrace.

Arifin, M. 1987. Philosophy of Islamic Education.Jakarta: Bina Aksara.

Arifin, Muhammad. 2003. Islamic Education: Theoretical and Practical Review Based on the Interdisciplinary Approach. Jakarta: PT. Earth Literacy.

Barizi, Ahmad. (Ed). 2011 Integrative Education Root of Tradition \& Scientific Integration Islamic education.Malang: UIN-Maliki Press.

Dwiningrum, Siti Irene Astuti. 2011 Decentralization and broad community participation Education: A Theoretical and Empirical Study.Yogyakarta: Student Library.

Eduaksi. Education 4.0, What is it? 2018. https://eduaksi.com/pendidikan-4-0apa/, accessed 11 February 2019 at 12.44 WIB.

Hamid, Edy Suandi. 2018. Disruptive Innovation: Benefits and Disadvantages Economic Development Context, https://law.uii.ac.id/wpcontent/uploads/2017/07/2017-07-27fh-uii-semnas-disruptive-innovationfaat-dan-kekurangi-dalam- economicdevelopment-context-Edy-SuandiHamid.pdf, accessed February 11, 2019. 
Kasali, Rhenald. 2017. Disruption "Nothing Can Be Changed Before Facing Just Motivation Is Not Enough "Facing the Invisible Opponents of the Uber Civilization.Jakarta: PT Gramedia Main Library.

Wisdom, Syamsul. 2007 Revitalizing Islamic Education. Yogyakarta: Graha Ilmu.

Mohammad Djazaman. 2009 The Concept of Islamic Education.Journal of Islamic Education. Volume 1.

Muhaiman. 2004. Islamic Education Paradigm. Bandung: PT. Teenager Rosdakarya.

Muhroqib. 2009 Islamic Education Yogyakarta: LKiS.

Rosidin. 2016 Islamic Education Problems in the Maqasid Shari'ah Perspective,
Maraji ': Journal of Islamic

Studies. Vol. 3, No. 1, hh. 186.

Saputro, Febrianto Adi. 2018. Mendikbud Reveals the Way to Face Revolution 4.0 in Education.

https://www.republika.co.id/berita/pendidi kan/eduaction/18/05/02/p8388c430mendikbud- revealed- the way to deal with-revolusi-40-di -pendidikan. accessed Monday 11 February 2019.

Suwardana, Hendra. 2017. Industrial Revolution 4. 0 Based on Mental Revolution. JATI UNIQUE .Vol.1, No.2, hh. 102-110 .

Zuhairini. 2015 Philosophy of Islamic Education. Jakarta: Bumi Aksara. 